\title{
IMPLEMENTATION OF THE SMART CITY CONCEPT IN THE EU: IMPORTANCE OF CLUSTER INITIATIVES AND BEST PRACTICE CASES
}

\author{
Davit ALAVERDYAN, Filip KUČERA, Martin HORÁK \\ Faculty of Management and Economics of Tomas Bata University in Zlín
}

\begin{abstract}
The Smart City concept is a challenge for all levels of public administration. With a growing degree of urbanization socio-economic problems accumulate in urban agglomeration. The Smart City concept has the potential to effectively address those issues by implementing relevant projects. Our main objective is to analyze Smart City concept in EU with emphasize to Smart Governance. Specifically, we investigate four areas related to Smart City concept, such as: the importance of Smart City Governance including Smart City manager role, the position of Smart City concept in EU policies, tools for it's promotion among EU countries and good practices of municipalities in implementing Smart City concept. The article was processed using analysis of relevant information sources. Regarding our results, the paper brings in an useful insight into Smart City manager role, concerned EU policies (especially 5G, Big data, ICT innovation and Internet of Things), tools as Smart City Clusters, Smart City living labs and examples including comparison of municipalities representing good practices (Amsterdam, Helsinki, Barcelona, Copenhagen, Vienna). In addition, we claim that the current concept of the Smart City within the EU institutions as well as within identified Smart City clusters and cities as examples of best practice is predominantly technological. However, professional discourse has shifted in recent years to the dimension of municipalities as an organizational and management component which lead to the idea of Smart Governance. Gathered findings could provide an inspiration to municipalities and their management in order to face new challenges related to the Smart City area.
\end{abstract}

\section{KEY WORDS}

Smart City, Smart Governance, Smart City Clusters, Living Labs, European Union.

\section{JEL CLASSIFICATION}

R10, O10, O20, O30.

\section{INTRODUCTION}

The smart city phenomenon is an increasingly popular concept emerging in both media and research papers. With connection to Smart City concept, the scholars use formulation as 
"ambiguous" or "fuzzy" (Waart et al., 2016; Caragliu et al., 2009). Despite the declared scope of the concept, there is a general consensus that the crucial for successful implementation of Smart City is the institutional support of municipalities. Emphasis is placed on the Smart Governance dimension respectively smart public administration. Let us note that among researchers initially dominated the strictly technological interpretation of the Smart City concept where ICT was considered to be the main driver of Smart City development. However, that discourse has shifted in recent years. Recently, the importance of municipalities as an organizational and management component is being taken into account (Waart et al., 2016). A number of researchers have connected the successful implementation of the Smart City concept with transformation and continuous changes in public administration, particulary in relation to citizen participation and emphasis on transparent decision making (Bolívar et al., 2016; Castelnovo et al., 2016). In order to successfully face these new challenges, the management of municipalities must be competent enough (Dameri, 2017). Nowadays, some EU countries are creating a special position for this issue - Smart City Manager (Michelucci et al., 2016), which will be further discussed within our paper. Regarding the situation in Europe, the European Union has gradually integrated the Smart City concept into its policies in recent years. Smart City initiative aims to make improvements in relation to a number of Europe 2020 targets. The European Commission defines its approach to Smart Cities as 'coordinated' and various parts of the Commission are collectively and independently involved in supporting Smart Cities. However, the approaches for promotion Smart City concept differ among EU countries. In this context, we point out successful tools and practice cases in order to inspire other countries. To sum up, the article aims to investigate following areas:

- the role of Smart City manager in Smart Governance,

- the position of Smart City in EU policies,

- applied tools for promotion Smart City concept among European countries,

- examples of municipalities representing good practices.

The article is structured as follows: Chapter 1 introduces research aims and used methodology, Chapter 2 focuses on describing Smart City Governance, role of Smart City manager and Smart City in EU policies; Chapter 3 defines tools for promotion Smart City in EU with good practices of municipalities, Chapter 4 presents results and discussion. Finally, conclusion and suggestions for the direction of future research are given.

\section{RESEARCH AIMS AND METHODOLOGY}

The main objective of our paper is to analyze Smart City concept in EU with emphasize to Smart Governance. Specifically, we want to point out that not only technological aspect of Smart Cities should be developed. It is equally important to improve the interaction between city and citizens where local governments play a crucial part. To face with this issue, we stated following research questions in our paper:

- What is the role and needed competences of Smart City manager in Smart Governance?

- What is the position of Smart City concept in EU policies?

- Which tools are used for promotion Smart City concept in EU countries?

- Which municipalities among EU countries represent good practice in implementing Smart City concept? 
Overall, the article was processed using the secondary data gathered through the literature the literature review was conducted. To fulfill mentioned research questions, we used following procedure:

- Firstly, we examined the monographies, studies, scientific articles from databases SCOPUS/WoS to describe Smart City governance and the role of Smart City manager including needed competences for that position. Selection criteria for searching were the following: date of publication from 1990 to 2017; used keywords for search: Smart City, Smart City manager, Smart Governance, Smart City manager competences. In addition, we identified masters programmes connected to the Smart City concept within this part of our work. In our case, FindAMasters database was used to find out relevant programmes, which have the keywords smart and city in their syllabus.

- Secondly, we analyzed Smart City concept in EU policies. Official documents by EU policy makers and monographies regarding area of Smart City concept were examined. With regard to the institutional framework of the Smart City concept in EU conditions, particular documents or programs such as Strategy Europe 2020, Mapping Smart Cities in the EU and European Innovation Partnership on Smart Cities and Communities were analyzed.

- Thirdly, we identified tools for promotion Smart City concept among EU countries, such as Smart City clusters and living labs. The identification was made on the basis of studied scientific articles from databases SCOPUS/WoS/Google Scholar. We used these criteria for search: date of publication from 1990 to 2017; including keywords Smart City, Smart Governance, Smart City innovation tools. Information of active Smart City clusters have been searched on Google requesting to the system to search on the web the keywords "Smart" and "Cluster" and within the biggest cluster mapping portal called European Cluster Collaboration Platform. Afterwards, the authors processed gathered information and analyzed selected clusters. The selection of analyzed clusters was made according to the amount of realised projects and their overall activity.

- Lastly, we analyzed five chosen municipalities. The selection criteria for chosing municipalities were especially given to the differing approach to the Smart Governance concept in selected municipalities. Important factor was also the relevance in relation to study Mapping Smart Cities in the EU (2014). After analyzing chosen municipalities, comparative analysis was made based on three criteria, such as: management of the cities, goals and vision, Smart City Initiatives. These three dimensions were choosen with a view to exploring issues of institutional aspects of the Smart City concept with regard to specific municipalities.

\section{THEORETICAL BACKGROUND}

As Odendaal (2003) states, the local governments are involved in planning and implementing the Smart City initiatives and therefore they generally play the director role in coordination of all other players in their region. In this context, scholars speak about Smart City Governance or Smart Governance (Nam \& Pardo, 2011; Chourabi et al., 2012; Meijer \& Rodríguez Bolívar, 2013; Scholl \& Scholl, 2014). Belissent (2010) claims that governance is the core of Smart City initiatives. The main role of governance is to bring these initiatives closer to citizens and enable them participation in implementing, monitoring, and evaluating these initiatives (Misuraca et al., 2011). Nam and Pardo (2011) list so called smart actions which help in forming the Smart City governance, such as: collaboration, cooperation, partnership, citizen engagement and participation. Castelnovo et al. (2016) suggest that holistic approach should be considered within Smart City Governance, including five dimensions: community 
building and management, vision and strategy formulation, public value generation, asset management, economic and financial sustainability.

The key is to create desirable connection between the city and its citizens. It leads to raise quality of life for citizens which is seen as one of the main objectives within Smart City initiatives (Shapiro, 2006; Giffinger et al., 2007). The aspect of managerial capabilities among local governments is very strong in this task (Torfing et al., 2012). In order to create such connection between governance, its citizens and furthermore successfully transform city into Smart City, the local governments must reach an appropriate level of competences. Generally, the term competences is defined by Le Boterf (1994) as "a recognized and proven set of representations, knowledge, skills and attitudes pertinently mobilized and combined in a given context". Rychen and Salganik (2003) suggest that "a competence is more than just knowledge or skills. It involves the ability to meet complex demands, by drawing on and mobilising psychosocial resources (including skills and attitudes) in a particular context. For example, the ability to communicate effectively is a competence that may draw on an individual's knowledge of language, practical IT skills and attitudes towards those with whom he or she is communicating".

However, as Dameri (2017) claims, there is a lack of competences in municipalities to manage the highest innovation and to follow modern trends in Smart City area. Dameri (2017) continues with statement that municipalities struggles with defining strategic planning for the Smart City implementation and manage the change program because the topic is too much immature and new. The other crucial fact is that local governments need official education to face such a complex topic as smart cities are (Dameri, 2017). This is supported by Hultin (2014) who mentions that one way to ensure the success of Smart Cities is to equip the new generation with the right set of skills for a smooth implementation of this dynamic concept. It is obvious that further education for managing and governing smart cities is needed within local governments. These findings are well understood by many universities/educational institutions which opened the masters programmes connected to the Smart City in order to develop appropriate competences in this area. According to the FindAMasters (2017) database, it was find out 40 master's degree programmes, which have the keywords smart and city in their syllabus. Some of them are more specialised and sophisticated, such as Smart City Design (Macromedia University); Energy for Smart Cities (offered by four European universities through InnoEnergy in France, Sweden, Belgium and Spain); MS in Urban Informatics (Northeastern University in Boston). These programmes could be seen as more technology-centered which is characterized by focusing on application domains that are heavily based on modern ICT (Michelucci et al., 2016). The other programmes are designed in more holistic way which is reflected by including a wider range of themes related to Smart City concept. Hence, these belong to the people-centered approach where technology and infrastructures are still important as enabling factors, but main topics are related to welfare, social inclusion, culture, and human capital (Caragliu et al., 2011). For example, it is:

- Integrative Urban Development - Smart City realised by University of Applied Sciences in Vienna. This programme is focused on developing 6 areas of competences, such as: project handling; scientific working; Smart City basics; Smart City competences; sociotechnical competences; business, management and law. Graduates of this programme find the application in infrastructure planning implementaion and maintenance or in management and urban planning such as city administration.

- Management of Smart Cities Master's Programme offered by DOBA Business School in Slovenia. The content is focused on: strategic management and leadership; advanced 
technologies; generating and managing innovation; global and sustainable development; communication and participation.

Overall, all of the available education programmes aim to make so called „smart people“ who are according to Castelnovo et al. (2016) "a fundamental asset for Smart Cities as they provide a relevant resource on which initiatives can rely to make cities smarter". Castelnovo et al. (2016) add that "smart, educated, and informed people can become active users and engage with Smart City initiatives". Furthermore, smart people "can make these initiatives a success or a failure, by both adopting and using the (smart) services made available to them and by participating in the governance and the management of the city" (Chourabi et al., 2012).

\subsection{The role and competences of Smart City Manager}

According to Wang (2015), crucial demand of Smart Cities is to improve the interaction between cities and citizens. This statement is also supported by Corrigan and Joyce (1997) and Nalbandian et al. (2013) who suggest that interaction between public management of municipalities and society is essential for the creation of effective services harmonized with the community needs. Nevertheless, as Michelucci et al. (2016) state, the increasing social problems are challenging public administrations to adopt new strategies in order to create smarter cities. In this context, there is an increasing need for better governance to manage initiatives or projects to make a city smart (Griffith, 2000). To follow this trend, some cities have created a dedicated organisational unit focused on planning and implementation of Smart City projects, led by Smart City Manager (Michelucci et al., 2016). Smart City manager operates as a horizontal actor, with responsibilities on projects developed in both hard and soft domains (Michelucci et al., 2016). Hence, he must be able to govern Smart City initiatives by integrating elements from multiple sectors. According to Michelucci et al. (2016), it is managerial role with a strategic vision, knowledge and responsibilities that cross several Smart City dimensions. From this point of view, Smart City manager should also be responsible for coordination and promoting the citizens' involvement and participation in planning. It leads to strengthen the city management and governance which is seen as one of key elements to claim city as smart (Nam \& Pardo, 2011). The position of manager can be found for example in Belgium, where 17 Belgian municipalities have one or several people in charge of Smart City (often named "Smart City Managers") and 59\% of Smart City managers are working into the strategic department of the municipality.

All changes in modern society are also reflected in the different set of competences required for manager role, Smart City manager is no exception. In the context of public manager competences, Virtanen (2000) identifies five categories, such as: task competence; professional competence in the work area; professional competence in the administration; political competence (about values, ideology and power); ethical competence (moral values and norms). However, literature related to Smart City managers and their competences is limited. The breakout in this context is made by Michelucci et al. (2016) who defined the role of the Smart City manager by identifying five main categories of required competences. Michelucci et al. (2016) list these five main competences:

- city planning capabilities (urban innovation, territorial planning and management of urban facilities, skills linked to the elaboration of a strategic, long term planning for sustainable urban services), 
- legal competences (the legal notions regarding big data/open data management, data security, legal aspects of public procurement, and the contractual issues involved in public-private partnerships),

- soft skills (empathy, flexibility, output oriented and open-mind behaviours, the ability to mediate conflicts and create relationships, strategic vision, project management attitudes and leadership capacity),

- financial resources management (instruments of public financing, new financial instruments, general knowledge of economic fundamentals),

- basic capacities (familiarity with ICT, knowledge of foreign languages, and past professional experiences).

\subsection{Smart City in EU policies}

Europe 2020 is the EU's strategy for boosting growth and jobs across the region in order to create a smart, sustainable and inclusive economy (EC, 2017). To further these aims, key targets within five areas have been set on at national and EU-wide levels to be achieved by the 2020, including employment, R\&D, climate change and energy, education, and poverty and social exclusion (EC, 2017).

Smart City initiatives can be considered a useful vehicle for cities to achieve their Europe 2020 targets. Cities as Smart entities may be particularly well suited to initiatives addressing local public goods problems, such as energy and climate change. Moreover, the impacts may be highly visible, especially compared with less densely populated areas. These are some potential uses and characteristics of Smart City initiatives:

- The Europe 2020 energy target could be addressed through initiatives that focus on Smart Environment or Smart Mobility.

- Smart Economy and Smart People initiatives are oriented towards employment and education targets, which include e-skills development. Moreover, improving citizens' skills should make them more employable which in turn supports the Europe 2020 employment targets.

- Smart Governance and Smart Living initiatives address poverty and social exclusion through measures including improvements to the quality of life, a focus on citizen connectivity (including e-government services) and the use of open data to create citizen services (EU, 2011).

A Smart City is a place where the traditional networks and services are made more efficient with the use of digital and telecommunication technologies, for the benefit of its inhabitants and businesses. With this vision in mind, the European Union is investing in ICT research and innovation and developing policies to improve the quality of life of citizens and make cities more sustainable in view of Europe's 20-20-20 targets (EC, 2017).

The European Commission (EC) defines its approach to Smart Cities as 'coordinated'; various parts of the EC are collectively and independently involved in supporting Smart Cities at international and national levels. For example, the Directorate-General for Communications Networks, Content and Technology has funded Smart City projects through 7th Framework Programme (FP7) projects and the ICT-Policy Support Programme (PSP) (EC, 2017a). The EC has provided policy support through particular policies of the Directorate-General for Mobility and Transport and via several communications that specifically refer to the role of Smart Cities (EC, 2017b). 
Most Smart City initiatives have the potential to support innovative growth and R\&D. They are funded by a variety of sources, including government and private companies, which share a common interest in progress in this area. To contribute to the innovation and R\&D target by further stimulating private sector R\&D investment, it is essential that projects are evaluated and lessons learnt from them to enable further development (EC, 2015).

Smart City initiative aims to make improvements in relation to a number of the Europe 2020 targets. For instance, a project that enhances mobility may make it easier for individuals to travel to the most appropriate school or job (thus contributing to the employment and education targets). This, in turn, can help alleviate location-based problems of poverty and social exclusion, although the impacts are likely to be less than the primary contribution to the energy and environment targets (EC, 2010).

In 2012 there were 143 ongoing Smart City projects of which 47 were located in Europe and 30 in the USA (Lee and Hancock, 2012). Cities have also been setting high targets for a clean future by taking part in initiatives and city networks such as Covenant of Mayors and Green Digital Charter. These were established to support the striving for the ambitious energy efficiency and $\mathrm{CO} 2$ reduction targets such as the European Union 2030 targets (Hannele, et al, 2016).

The Smart City concept goes beyond the use of ICT for better resource use and less emissions. It means smarter urban transport networks, upgraded water supply and waste disposal facilities, and more efficient ways to light and heat buildings. And it also encompasses a more interactive and responsive city administration, safer public spaces and meeting the needs of an ageing population (EC, 2017).

To speed up the deployment of these solutions, the European Commission has initiated the European Innovation Partnership on Smart Cities and Communities (EIP-SCC) that will bring together European cities, industry leaders, and representatives of civil society to smarten up Europe's urban areas, in July 2012 (EC, 2017). So far, the EIP-SCC has received some 370 commitments to fund and develop smart solutions in the areas of energy, ICT and transport. These commitments involve more than 3,000 partners from across Europe and create a huge potential for making our cities more attractive, and create business opportunities (EC, 2017). There exist several related policies in regard to the Smart City targets in the EU. Polices related to Smart City development includes:

- $5 \mathrm{G}$

- Big data

- ICT innovation

- Internet of Things

The European Commission signed a landmark agreement with the "5G Infrastructure Association' on 17 December 2013, representing major industry players, to establish a Public Private Partnership on 5G (5G PPP). This is the EU flagship initiative to accelerate research developments in $5 \mathrm{G}$ technology. The European Commission has earmarked a public funding of $€ 700$ million through the Horizon 2020 Program to support this activity. EU industry is set to match this investment by up to 5 times, to more than $€ 3$ billion euros.

Good use of data can bring opportunities also to more traditional sectors such as transport, health or manufacturing. Improved analytics and processing of data, especially Big Data, will make it possible to: 
- transform Europe's service industries by generating a wide range of innovative information products and services;

- increase the productivity of all sectors of the economy through improved business intelligence;

- better address many of the challenges that face our societies;

- improve research and speed up innovation;

- achieve cost reductions through more personalised services

- increase efficiency in the public sector (EC, 2017).

Scaling-up the ICT innovation ecosystem in Europe. The Commission works to improve innovation in Europe by providing instruments that enhance research, entrepreneurs and companies. Internet of Things (IoT) merges physical and virtual worlds, creating smart environments. For the past six years, the European Commission has been actively cooperating with the industry and various organisations as well as with EU Member States and third countries to unleash the potential of the IoT technology (EC, 2017).

In the institutional environment of the EU the technological aproach to Smart City concept prevails. Beyond the EU's policy framework, it is possible to rely on a number of definitions of the Smart City concept in the literature. In the past, the emphasis on technology prevailed. However, lately there is a shift towards wider Smart Governance approach.

One of the oldest and the most complex definitions of Smart City was described by Giffinger et al. (2007). Smart City has been divided into six dimensions - smart governance, smart people, smart economy, smart mobility, smart environment and smart living. According to Mulder (2014), the city government is responsible for implementing relevant technologies that will primarily enhance the quality of life of citizens, and criticizes innovations primarily driven by interest on the supply side of technological companies.

Emphasis on the participatory aproach to the concept can be found in many different papers in recent years. For example, Caragli et al. (2011) describes Smart City as a place where investments in human and social capital and traditional industries (transport, energy) as well as modern digital technologies are stimulated by sustainable economic growth with an emphasis on high quality of life, sustainable use of natural resources and participative governance. Meijer and Bolivar (2016) states that the city's smartification process is related to the ability to activate human capital and involvement of various stakeholders (institutions and individuals) through the use of modern digital technologies. In this context, Nalbandian et al. (2013) suggest that interaction between public management of municipalities and society is essential for the creation of effective services.

\section{TOOLS FOR PROMOTION SMART CITY IN EU - SMART CITY CLUSTERS, LIVING LABS AND BEST PRACTICE CASES}

The chapter describes selected measures to support the widening of the general awareness of the Smart City concept across the EU. It focuses primarily on the co-operation of institutionalized actors through cluster initiatives, participation of the public and other actors through Smart Living Labs and also mentiones the most frequently described examples of specific cities as successful cases of Smart City implementation.

\subsection{Smart City Clusters}


Recently, the idea of clusters/clustering appear in fulfilling the Smart City concept. The cluster is defined as "geographic concentrations of interconnected companies, specialized suppliers, service providers, firms in related industries and associated institutions (universities, standards agencies, and trade associations) in particular fields that compete but also cooperate" (Porter, 1990). Being a cluster member is one of the few ways for SMEs how to be competitive in comparison to the large companies. According to Zagorsek et al. (2008), cluster members gain many competitive advantages, such as "increasing returns in the context of globalization, reduced transaction costs, externality benefits, improved quality, positive effects of collective learning and high growth led by innovation." It follows that clusters further enhance business performance, resource efficiency, economies of scale, and new opportunities. On Figure 1 below are clusters operating in smart area, which were identified by the authors of this paper. Furthermore, Table 1 reflects analysis of selected Smart City Clusters in Europe.

Figure 1-Smart City Clusters in Europe, own processing

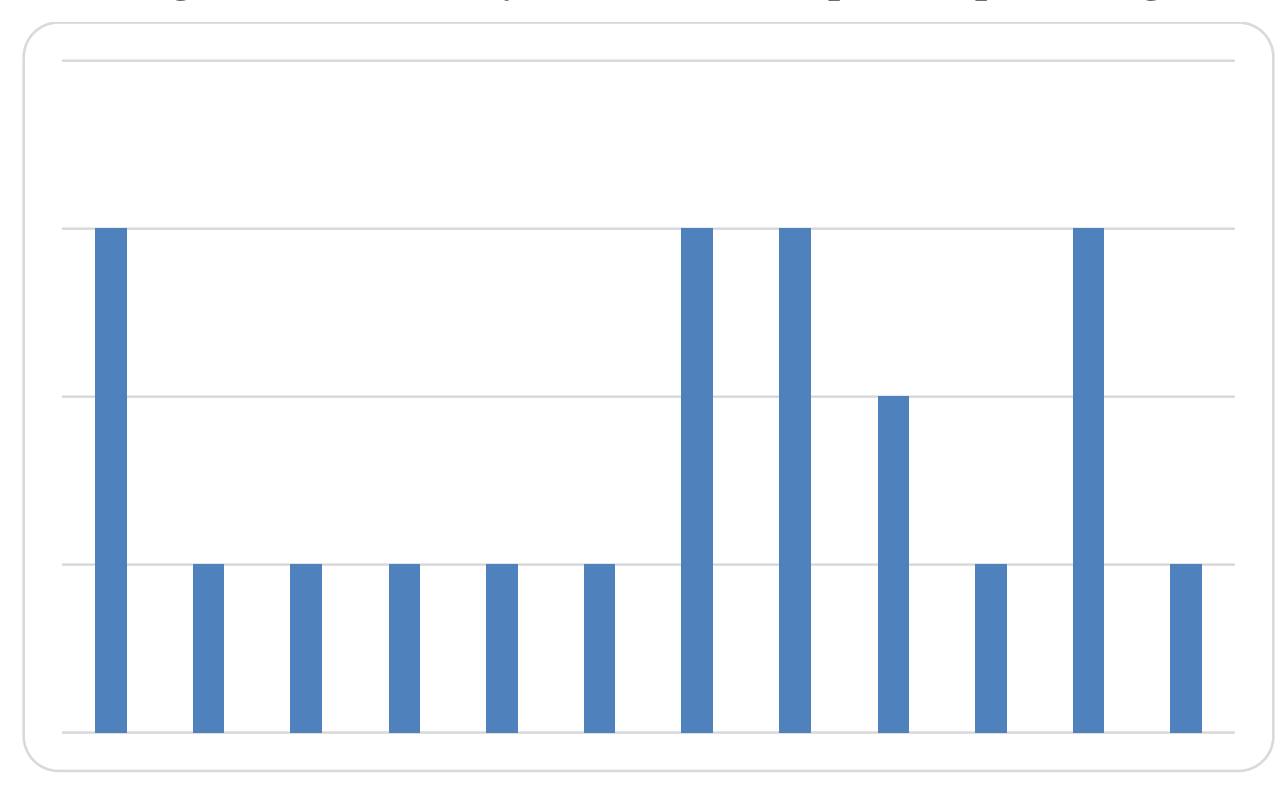




\section{Tab. 2 - Selected Smart City Clusters in Europe, own processing}

\begin{tabular}{|c|c|c|c|}
\hline $\begin{array}{l}\text { Name of the } \\
\text { cluster }\end{array}$ & Main focus and developed areas of the cluster & Place of the cluster & Source \\
\hline Smart City Cluster & $\begin{array}{l}\text { The cluster brings solutions through pilot projects in } 3 \text { categories, such as: } \\
\text { smart public transportation, smart governance, smart infrastructure. Main } \\
\text { focus of the cluster is given to: } \\
\text { - ICT in different activities and processes of the cities, } \\
\text { - ICT and other technologies in developing healthcare and social } \\
\text { welfare in an efficient and cost-effective way, } \\
\text { - energy saving in constructing and maintaining different buildings. }\end{array}$ & $\begin{array}{c}\text { The cluster operates in } \\
\text { Estonia. }\end{array}$ & http://smartcitylab.eu/about \\
\hline $\begin{array}{c}\text { Czech Smart City } \\
\text { Cluster }\end{array}$ & $\begin{array}{l}\text { The mission of cluster is to develop a unique partnership between } \\
\text { companies, government, self-government, knowledge institutions and urban } \\
\text { citizens. The main tools of support are: } \\
\text { - transformation related to knowledge of development and research } \\
\text { into the environment of cluster members, } \\
\text { - the strengthening links to scientific and research institutions, } \\
\text { - the joint development of know-how in the field of social, technical } \\
\text { and economic solutions, } \\
\text { - the popularization of the smart cities concept. } \\
\text { The cluster members are focused on integration of smart technologies such } \\
\text { as energy, smart buildings, transport and ICT. }\end{array}$ & $\begin{array}{l}\text { The cluster operates in } \\
\text { Czech Republic. }\end{array}$ & http://czechsmartcitycluster.cz \\
\hline $\begin{array}{l}\text { Cluster Andalucía } \\
\text { Smart City }\end{array}$ & $\begin{array}{l}\text { The cluster formulates } 4 \text { main goals: } \\
\text { - to create Smart Cities: sustainable, efficient and comfortable } \\
\text { (designs, develops and promotes smart }- \text { environmentally } \\
\text { sustainable - cities), } \\
\text { - to generate wealth and jobs in the cities, }\end{array}$ & $\begin{array}{c}\text { The cluster operates in } \\
\text { region of Andalusia in } \\
\text { Spain. }\end{array}$ & http://www.andaluciasmartcity.com \\
\hline
\end{tabular}




\section{sciendo}

\begin{tabular}{|c|c|c|c|}
\hline & $\begin{array}{l}\text { - to base action on } \mathrm{R} \& \mathrm{D} \text {, } \\
\text { - to cooperate among sectors (connects businesses and institutions } \\
\text { from diverse sectors, such as energy, environment, transport, ICT, } \\
\text { mobility...). }\end{array}$ & & \\
\hline Smart City Tech & $\begin{array}{l}\text { Smart City Tech is a European Strategic Cluster Partnership which aims to: } \\
\text { - develop a joint vision on smart systems for urban areas which will } \\
\text { lead to concentrating available resources, } \\
\text { - build a global ecosystem of companies, policy makers, academia, } \\
\text { investors and citizens ready for joint projects, } \\
\text { - develop global innovation capacities which allows for efficient } \\
\text { development of new smart systems solutions for urban areas, } \\
\text { - stimulate active collaboration between stakeholders on concrete } \\
\text { projects leading to added value for all ecosystem stakeholders } \\
\text { involved, } \\
\text { mobilize funding, either public or private money, as key resource } \\
\text { to drive SmartCityTech projects forward. }\end{array}$ & $\begin{array}{l}\text { The cluster operates in } \\
\text { Belgium, associates } \\
\text { international members } \\
\text { from: Denmark, Germany, } \\
\text { Spain, France and Italy. }\end{array}$ & http://www.smartcitytech.eu/ \\
\hline $\begin{array}{l}\text { The Technologies } \\
\text { for Smart Cities \& } \\
\text { Communities - } \\
\text { Lombardy Cluster }\end{array}$ & $\begin{array}{l}\text { The cluster promotes and facilitates research to support innovation, in order } \\
\text { to design, develop and implement the most advanced technology solutions } \\
\text { for the integrated management system of urban and metropolitan scale. The } \\
\text { focus is mainly given to: } \\
\text { - renewable energy and efficiency energy, } \\
\text { - security and territorial monitoring, } \\
\text { - mobility, } \\
\text { - health, } \\
\text { - wellness, } \\
\text { - e-government and justice, } \\
\text { - education and training, } \\
\text { - cultural heritage and tourism }\end{array}$ & $\begin{array}{l}\text { The cluster operates in } \\
\text { region of Lombardy in } \\
\text { Italy. }\end{array}$ & http://www.clusterscclombardia.it/ \\
\hline
\end{tabular}




\begin{tabular}{|c|c|c|c|}
\hline $\begin{array}{c}\text { EUREKA's Smart } \\
\text { City: EUREKA's } \\
\text { inter-Cluster } \\
\text { initiative }\end{array}$ & $\begin{array}{c}\text { Initiative is gathering all EUREKA Clusters, namely: } \\
\text { - } \begin{array}{c}\text { ACQUEAU (innovation in water sector), } \\
\text { Celtic Plus (telecommunication and ICT), }\end{array}\end{array}$ & $\begin{array}{c}\text { The cluster operates in } \\
\text { Brussels. }\end{array}$ & $\begin{array}{l}\text { http://www.eureka-smart- } \\
\text { cities.org/clusters/ }\end{array}$ \\
\hline $\begin{array}{c}\text { - EUROGIA2020 (innovative energy technologies), } \\
\text { Smart IT Cluster }\end{array}$ & $\begin{array}{c}\text { Cluster's main objective is to develop integrated and innovative IT solutions } \\
\text { for the agricultural, energy and banking sectors. }\end{array}$ & $\begin{array}{c}\text { The cluster operates in } \\
\text { Lithuania, associates } \\
\text { international members from } \\
\text { Belorussia, Latvia, Poland, } \\
\text { Ukraine, Russia }\end{array}$ & http://smartitcluster.eu \\
\hline $\begin{array}{c}\text { Smart Cities } \\
\text { Mediterranea } \\
\text { Cluster }\end{array}$ & $\begin{array}{l}\text { The scope of the Partnership is to identify, develop and deploy replicable, } \\
\text { balanced and integrated solutions in the energy, transport, and ICT, in small } \\
\text { and medium sized cities and islands in the Euro-Mediterranean region. }\end{array}$ & $\begin{array}{c}\text { The cluster operates in } \\
\text { Euro-Mediterranean region, } \\
\text { group members from 26 } \\
\text { countries. }\end{array}$ & http://www.smartcitiesmed.com/ \\
\hline
\end{tabular}




\subsection{Smart Living labs}

Secondly, living labs are used as a tool to promote Smart City concept (Cosgrave et al., 2013; Bifulco et al., 2014; Bifulco et al., 2017). Living labs could be seen as a supplement to traditional cluster and regional innovation policy (Almirall \& Warenham 2008). Bifulco et al. (2017) suggest, that the implementation of living labs brings together city managers and all the urban actors. Schaffers and Turkama (2012) defined living labs as places where multiple actors collaborate to achieve common aims through resource integration, new technologies, and continuous relationships. The European project CoreLabs described them as "a system enabling people, users/consumers of services and product, to take active roles as contributors and cocreators in the research, development, and innovation process" (Arnkil et al., 2010). It could be stated that creating such labs lead to fostering relationships among stakeholders which is also important element in cluster conditions. Living labs were created for example in Amsterdam, Barcelona and Helsinki (Bifulco et al., 2017). Stakeholders in either clusters or living labs are usually represented by the following three spheres - science (universities, research-and-development units, science supporting institutions, etc.), industry (enterprises) and government (including regional and local selfgovernments). These three spheres represent the triple helix which was proposed in the 1990s by Etzkowitz and Leydesdorff (1995). Developing interactions between mentioned three spheres is crucial to regional development (Leydesdorff \& Etzkowitz, 2001). However, some authors add the fourth sphere - users/citizens - which is characteristic for quadruple helix (Waart et al., 2016; Carayannis \& Campbell, 2009). Apparently, user-driven innovation approaches are seen as an essential element to SMEs, because it could open up new possibilities to participate in innovation activity (Arnkil et al., 2010). Santoro and Conte (2009) found out that entities within living lab argue that such user-driven innovation can help the SMEs to shorten the incubation time and also minimize the risks associated to the development of new products/services. According to Arnkil et al. (2010), the development possibilities of SMEs are very much dependent on how well they can involve users in their innovation activities. These findings should be considered by management entities of either clusters or living labs in order to succeed.

\subsection{Examples of best practice cases: Amsterdam, Helsinki, Barcelona, Copenhagen and Vienna}

Selected best practice cases rely on the research objectives emphasizing that not only technological aspect of Smart Cities should be developed. It is equally important to improve the interaction between city and citizens where local governments play a crucial part with respect to transparency and participatory governance.

Listed cases describe the elements of Smart Governance concept from various points of view. For example, in the case of Amsterdam, it is a network of living labs (Health Lab). Policy makers in Helsinki focused on open data. Vienna and Copenhagen are looking for a participatory approach to mobility projects. Barcelona emphasizes transversely and cooperative knowledge as one of the pillar of its strategy. The purpose of the chapter is to provide an insight into the specific Smart City solutions, which moves traditional orientation on technologies further. The relevance of these examples is based on study Mapping Smart Cities in the EU, published by the European Parliament in 2014.

The authors have the ambition to continue with research and explore how Smart City activities can also work in smaller municipalities. The mentioned study Mapping Smart Cities in the EU (2014) included only settlements with a population of more than 100,000 . This offers the research gap for a more detailed analysis of the Smart City concept also in smaller settlements of regional significance. 


\section{Amsterdam}

Amsterdam, generally considered the first Smart City in the world, defines a Smart City considering both infrastructures and people, and especially the quality of life for every citizen (ASC, 2017).

Before starting the Amsterdam Smart City (ASC) project in 2009, Amsterdam Living Lab (ALL) had already been launched in 2008 to test new products for several firms. The ALL played a crucial role in the city's smart development as it led to collaborations both inside and outside the city. Widespread collaborations also took place among inhabitants, local businesses, research centers and local agencies regarding environmental issues; additionally, Amsterdam was involved in ENOLL to benefit from resource integration with actors dealing with smart projects in Europe (Francesco, et al. 2017).

Amsterdam set out its sustainability targets in the Structural Vision 2040 (CoA, 2011) and the Energy Strategy 2040 (CoA, 2011(a)). In these documents they stated the ambitions of:

- climate-neutral municipal organisation in 2015,

- $40 \%$ reduction in $\mathrm{CO} 2$ emissions in 2025, compared with 1990 levels,

- $75 \%$ reduction in $\mathrm{CO} 2$ emissions by 2040 .

To help achieve these targets, the Amsterdam Innovation Motor (AIM), now Amsterdam Economic Board (AEB, 2017), the city of Amsterdam, net operator Liander and telecom provider KPN started the Amsterdam Smart City platform in 2009. The Amsterdam Smart City (ASC) platform is a partnership between businesses, authorities, research institutions and the people of Amsterdam that initiates, stimulates and advances Smart City projects in Amsterdam. This platform has one central office with several people working on the Smart City platform. In 2013 this platform has grown into a partnership with over 70 partners who are engaged in 37 different Smart City projects (ASC, 2017). Europe 2020 targets are covered by all Smart City initiatives in Amsterdam. There were several solutions introduced in the Smart City Amsterdam. Some of them are introduced below.

a) The 'Klimaatstraat'

'Klimaatstraat' (climate street) is a holistic concept for shopping streets with a focus on a number of different aspects: public space, logistics and entrepreneurial spaces. This project combines physical and logistical initiatives in the public space, as well as sustainable initiatives within present businesses. Objectives of the Klimaatstraat Project, as defined by Smart Stories, include the reduction of CO2 emissions and energy consumption in Utrechtsestraat (ASS, 2011) This was to be achieved through a combination of sustainability initiatives (sustainable waste logistics, energy displays, LED lighting, smart meters and energy management systems) and the related changes in user behaviour (CoA, 2011).

b) Ship-to-grid (green energy)

The Port of Amsterdam has the ambition to become one of the most sustainable harbours in Europe by 2020 and has invested in the ship-to-grid electricity project to achieve this (ASS, 2011). This project allows inland ships in the harbour of Amsterdam to use green energy from the grid instead of their own stationary diesel generators. This reduces $\mathrm{CO} 2$ emissions and leads to less noise and air pollution. The ICT component of this project is that ship owners can pay via a telephone payment system. In total, 195 ship-to-grid connection points are installed in the Amsterdam harbour (Tan, 2016).

c) Smart building management systems (ITO Tower Project)

The Smart Building Management System Project was aimed at reducing energy use and operating costs for office buildings. This pilot project ran in the ITO Tower, the head office of Accenture in the Netherlands, where various Smart Energy management solutions were deployed. The main objective was to reduce energy consumption by collecting, analysing and visualising data about the amount of energy consumed and applying energy saving strategies based on this information (ASS, 2011). 
d) Health Lab

Health Lab is a network of living labs in the Amsterdam region bringing together researchers, government, practitioners and healthcare users in the field of ICT technologies and innovative healthcare solutions. The programme was initiated by the AIM (ASC platform founder) and various research, business and governmental partners. The programme focuses on increasing the efficiency of technological innovation in the health sector and circulates around scientists, practitioners and entrepreneurs. End-users play a central role and ICT is considered the most important enabler (ASC, 2013).

\section{Helsinki}

The network of Smart City initiatives and projects in Helsinki is coordinated by Forum Virium, a private non-profit organisation owned by the city of Helsinki. As an urban innovator and initiator of public-private partnerships, it has the aim of developing new urban digital services in collaboration with the private sector, the municipality, public sector organizations and Helsinki residents (GSMA, 2012).

a) Open data platform (Helsinki Region Infoshare)

Opening up public data plays an important role in Helsinki's Smart City developments. The Helsinki Region Infoshare Project aims to make regional information from public organisations more easily accessible to the public. The data are free of charge and can be used by businesses, academia and research institutes, governmental institutes or citizens. In July 2013, over 1,030 databases were available at the website, covering a wide range of urban phenomena, such as living conditions, employment, transport, economics and well-being. Geo-referenced, geographic information system data are well represented in this dataset (HRI, 2013).

b) Finnish Living Lab

The Finnish Living Lab in Helsinki directly focused on urban innovation, rather than on new products. Public organizations, local agencies, and citizens acted together to attain innovative community services through digital instruments. Moreover, user-driven innovation was particularly promoted and only after achieving the first outcomes related to public services, firms were allowed to test innovation they deployed internally. Smart City solutions applied in Helsinki are introduced below (Francesco, et al, 2017).

\section{Barcelona}

The city of Barcelona has got the ambition to become a model Smart City for the whole world. Its vision is to:

- integrate the information technologies in the city,

- relate the different areas and sectors,

- find synergies and added value,

- generate transversely and cooperative knowledge (MCoE, 2012).

a) The 22@Barcelona

The 22@Barcelona district created a Living Lab to support business innovation and to enable better usage of public spaces. The positive outcomes achieved led the city managers to promote new initiatives built around public services, transport, ecology, and ICTs. The role of universities was fundamental in teaching how to manage relationships in LLs and in promoting a culture of open innovation based on citizens and making the city an open laboratory. The key results are related to creativity, innovation, culture and knowledge (Francesco, et al, 2017). 
b) Smart parking

The introduction of wireless sensors at parking places can ease city traffic by showing car drivers where there are free parking spaces. The information is sent to a data centre and made available for smart phones sending real-time data to users. In this way the system guides the driver to the nearest parking spot (MCoE, 2012).

\section{Copenhagen}

Copenhagen has a vision to become the world's first carbon-neutral capital by 2025 (CoC, 2009). Therefore, the city is currently implementing a range of new and innovative solutions within the fields of transport, waste, water, heating and alternative energy sources to support this aim and improve sustainability, in many initiatives. By testing these solutions, the city hopes to attract innovative companies, which will in turn support the economy through the process of becoming greener and smarter. At the same time, the city is working to increase growth and improve the quality of life of its inhabitants. This vision is supported by clear targets in different sectors. For example, Copenhagen has the objective to increase the number of people 'cycling to work and education from $35 \%$ in 2011 to $50 \%$ by 2050 ' and to reduce 'each Copenhagen citizen's (water) consumption from 100 litres per day to 90 litres per day in 2025 ' (C.C.C., 2014). The city of Copenhagen has deployed many concrete projects, which are described and assessed as potential solutions below.

a) Cycling

Copenhagen has an extensive network of cycle lanes, which is still being expanded. In 2011, 35\% of commuters went to work by bicycle. Urban planning takes cycling infrastructure into account as a crucial parameter of the city's traffic concept. Cycle lines are built in a way to reduce time and improve safety (SoC, 2012). This is achieved by installing specific traffic lights for bicycles that (in the future) turn green when cyclists are travelling at a certain speed (GtC, 2017).

Another feature of this solution is a project called The Copenhagen Wheel. This allows bicycles to become Smart by equipping them with sensors in their wheels. These sensors measure environmental data like 'noise pollution, congestion and road conditions'. The collected data are sent anonymously to the city in order to analyse environmental factors and measure the impact of traffic on the city infrastructure; furthermore the data may be fed into the decision-making process when environmental or transportation issues are on the agenda (Maroula et al, 2016).

\section{Vienna}

Vienna was listed as the world's number one Smart City in 2011 and ranked fourth in the European list of Smart Cities of 2012. The Smart City project of the Austrian Capital Vienna runs under the direction of the Vienna city administration. In order to reduce energy consumption and emissions without renouncing quality of life the city is continuously modernised. The project is long term and covers all areas of life, work and leisure activities. It includes infrastructure, energy and mobility as well as all aspects of urban development (Cohen, 2013). Solutions deployed in the Smart City Vienna included:

a) Integrated mobility concept 'SMILE'

Smart Mobility Info and Ticketing System Leading the Way for Effective E-Mobility Services (SMILE) is the prototype of a multi-modal mobility platform. The platform aims to cover all public and individual mobility services for customers, providing comprehensive Information on the various options for getting from A to B. It is developed in a joint research project by two cityowned enterprises (public utility company Wiener Stadtwerke and public transport operator Wiener Linien) and the Austrian Federal Railways (ÖBB) (SCW, 2017).

b) Mobility solution 'eMorail'

eMorail is a demonstration project, which aims to produce a blueprint for an innovative, costefficient and environmentally friendly mobility solution for commuters. It has been implemented in 
the cities of Vienna and Graz. Core elements of the project are an integrated transport service and an intermodal e-car sharing and e-bike service. Commuters should have a ticket for the Austrian Federal Railways as well as access to the use of an e-vehicle at their place of residence and destination. Additional services such as information and repair are intended to complete the package. eMorail maintains a smart phone application, which increases accessibility for customers (CEF, 2013).

\section{RESULTS AND DISCUSSION}

Considering the first research question, we found out that some municipalities implemented a specific position to manage a Smart City initiative. In connection with the Smart Governance enter into the forefront also need of competent human resources - in the ideal case, the Smart City Manager position (e.g. in Belgium). In this research area, we brought an overview of that role in available literature. To succeed in that role, it is needed to have appropriate competences, such as: city planning capabilities, legal competences, soft skills, financial resources management and basic capacities (Michelucci et al., 2016). According to Kourtit et al. (2014), the importance of management of financial resources is decisive for the prosperity and sustainability of Smart Cities over time. Meanwhile, competences connected to city planning capabilities and basic capacities are included in management of city infrastructures and ICT infrastructures as enabling factors for Smart City development (Castelnovo et al., 2016). However, it needs to be mentioned that research by Michelucci et al. (2016) is pioneer one in the area of Smart City manager and his/her competences. The topic is new, and the further investigation about his/her position and role needs to be done.

Speaking about the second research question, there exist several related policies in regard to the Smart City targets in the institutional level of EU. In this context, we emphasize the coordinating role of The European Commission. Polices related to Smart City development includes especially folowing digital agendas: 5G, Big data, ICT innovation and Internet of Things. According to the studied documents, it could be said that the current concept of the Smart City within the EU institutions is predominantly technological.

The third investigation area was focused on tools used for support Smart City. Based on gathered findings, we identified two main tools for promotion Smart City concept in EU countries, namely Smart City clusters and living labs. Regarding identified clusters, it should be noted that agenda of their activity is mainly focused on technological aspects of Smart City concept. This consists mainly of developing areas related to the energy, transport, and ICT. Nevertheless, in analyzed clusters lack activities to improve the interaction between city and citizens which is crucial factor for Smart City development according to Wang (2015), Corrigan and Joyce (1997) and Nalbandian et al. (2013). On the other hand, in some cities, especially in connection with projects of Smart Living Labs, which brings together city managers and all the urban actors, it begins to develop a participative dimension of the Smart City concept. Living labs appear to be one of the main initiatives in City of Helsinki and Barcelona.

Regarding the fourth research question, we deeply investigated five municipalities: Amsterdam, Helsinki, Barcelona, Copenhagen and Vienna. We claim that cities have different approaches to their 'smart' development, however there are several similarities and differences between the cities. Results of comparing three areas (management of the cities, goals and vision, Smart City initiatives) in these municipalities are presented below:

- Management of the cities: There is a quite big similarity between the management and administrative types in all presents cases. Smart City initiatives, involved organizations and cooperation is based on public and private partnership. Mainly, municipalities of the cities are the main accountable bodies for the Smart City goals of their cities. Smart City initiatives in 
Helsinki are coordinated by the Forum Virium, which is nonprofit organization working under the city administration. Meanwhile in Vienna, Copenhagen and in Barcelona the administration of the cites is the direct coordinator of the Smart City projects.

- Goals and Vision: Above mentioned cities have clear vision and goals related to the Smart City initiatives. However, goals and vision of the cities differ. If the city Copenhagen wants to become world's first carbon-neutral capital by 2025, municipality of Barcelona has a goal to make a model Smart City in the whole world. The administration of the Vienna city has some similar goals as like in Copenhagen related to reduction of energy consumption and emissions without having an impact on quality of life in the city. City of Amsterdam also tries to address environmental issues with the Smart City goals, while city of Helsinki is more concentrated on ICTs and digital adoption of the city.

- Smart City Initiatives: Living labs (LLs) appear to be one of the main initiatives in City of Helsinki and Barcelona. However, the main goal of the LLs are vary in both cities. LLs in Barcelona are initiated to support business innovation and to utilize public spaces efficiently. City of Helsinki uses LLs for the urban innovations and it is based on the public and private cooperation and initiatives. City of Vienna and Copenhagen have similar initiatives that are built to coordinate public transport and mobility in the cities. Smart Mobility Info and Ticketing System Leading and eMorail initiatives in Vienna, The Copenhagen Wheel and many other smart approaches are making the public mobility easier and faster in both cities. City of Amsterdam is leading in all directions with its initiatives. Municipality of Amsterdam is accomplishing all types of Smart City projects mentioned in all other cities.

\section{CONCLUSION}

This paper reacts to an intensified interest in the field of the Smart City concept. The main objective of our paper was to analyze Smart City concept in EU with emphasize to Smart Governance. The paper was processed using secondary data only concerning relevant information sources, especially from the Scopus/WoS database. Firstly, we described the role of Smart City manager including his/her competences for effective performance at this position. However, the data in this area are limited only to the research by Michelucci et al. (2016) and partially in studies by Kourtit et al. (2014) and Castelnovo et al. (2016). Secondly, the documents related to Smart City concept by the European Commission was analyzed and compared to the opinions of scholars in the literature. Thirdly, we looked at the tools applied for promotion Smart City concept in EU countries. In this context, Smart City clusters and living labs were identified. Lastly, we presented five municipalities (Amsterdam, Helsinki, Barcelona, Copenhagen and Vienna) considered as good practices in implementing Smart City concept. These municipalities were also compared in three dimensions, such as: management of the cities, goals and vision, Smart City initiatives.

Our paper have several implications for practice, especially for educators and municipalities. Nowadays, municipalities struggle with implementing Smart City concept due to the lack of competences. Thus, further education for managing and governing Smart Cities is needed within local governments. This is important especially for universities and their curriculums. They must try to update their syllabus to face current needs related to implementing Smart City concept within governments. In this context, having competent human resources is essential factor to become Smart Governance. Regarding next implication, position of Smart City manager together with tools such as clusters and living labs might be inspiring for municipalities in order to successfully transform city into Smart City. However, we suggest that not only technological aspects should develop, but also connection between the city and its citizens. It is needed to create a bond and involve citizens into city development which leads to raise quality of their life. 
It is desirable that the future research of the Smart City concept should focus on the general preparedness of the muncipalities with regard to the quality of human resources, the ability of strategic planning and transparency and co-operation with other actors involved in city development. This is in line with further research undertaken by the authors. As the Nam \& Pardo (2011) say, strengthen the city management and governance is seen as one of key elements to claim city as smart. Further research in relations to Smart Governance approach pushing the entire concept beyond the boundless of dominant technological projects whose implementation in municipalities of regional significance is often too costly or ineffective.

\section{ACKNOWLEDGEMENT}

The authors are thankful to the Internal Grant Agency of UTB IGA/FaME/2016/010 - "Evaluation and management of cohesion policy interventions in relation to territorial development, with emphasis on the thematic area of smart city," which provided financial support for this research.

\section{REFERENCES}

Almirall, E. \& Wareham, J. (2008). Living Labs and Open Innovation: Roles and applicability. The Electronic Journal for Virtual Organizations and Networks, Special Issue on Living Labs. eJOV, Vol. 10, pp. 21-46.

Amsterdam Economic Board (AEB). (2017). Project on Amsterdam Innovation Motor. Available at: https://www.amsterdameconomicboard.com/.

Amsterdam Smart City (ASC). (2013) Health-Lab', Amsterdam Smart City, 2013b, available at: http://amsterdamsmartcity.com/projects/detail/label/Health-Lab.

Amsterdam Smart Stories (ASS) (2011). Published by Amsterdam Smart City initiatives. Available at: https://issuu.com/amsterdamsmartcity/docs/smart_stories.

Arnkil, R., Järvensivu, A., Koski, P., \& Piirainen, T. (2010). Exploring quadruple helix outlining user-oriented innovation models.

Belissent, J. (2010). Getting clever about smart cities: New opportunities require new business models. Cambridge, MA: Forrester Research.

Bifulco, F., Tregua, M., \& Amitrano, C. C. (2014). Living labs for smart innovation: a user-centric approach, The Human Side of Service Engineering, 1, 282-294.

Bifulco, F., Tregua, M., \& Amitrano, C. C. (2017). Co-Governing Smart Cities Through Living Labs. Top Evidences From EU, Transylvanian Review of Administrative Sciences, 13(50), 21-37.

Bolívar, M., P., R. and Meijer, A. (2016). Governing the smart city: a review of the literature on smart urban governance, International Review of Administrative Sciences, Vol 82, Issue 2.

Caragliu, A., C., Del Bo, and P. Nijkamp, (2011). Smart cities in Europe, Journal of Urban Technology, 18:2; 65-82.

Carayannis, E. G., \& Campbell, D. F. (2009). Mode 3 and Quadruple Helix: toward a 21st century fractal innovation ekosystém, International journal of technology management, 46(3-4), 201234.

Castelnovo, W., Misuraca, G., \& Savoldelli, A. (2016). Smart cities governance: The need for a holistic approach to assessing urban participatory policy making, Social Science Computer Review, 34(6), 724-739.

City of Amsterdam, (2011a). Amsterdam a different energy 2040 Energy Strategy, City of Amsterdam, Klimaatbureau, Amsterdam.

City of Amsterdam. (2011). Economically strong and sustainable Structural Vision: Amsterdam 2040, PlanAmsterdam, No. 1-2011, City of Amsterdam, Dienst Ruimtelijke Ordening, Amsterdam. 
City of Copenhagen. (2009). Copenhagen Climate Plan The short version. The Technical and Environmental Administration City Hall.

Climate and Energy Fund. (2013). eMORAIL, Integrated eMobility Service for Public Transport, available http://www.klimafonds.gv.at/assets/Uploads/Themenprojekte/Leuchttuerme/eMORAIL/2205 2012EMORAILBeschreibung-EN.pdf.

Cohen B. (2012). The Top 10 Smart Cities on The Planet, available at: http://www.fastcoexist.com/1679127/thetop-10-smart-cities-on-the-planet.

Copenhagen Cleantech Cluster (CCC) (2014). Copenhagen: Solutions For Sustainable Cities. Published by Copenhagen City Hall.

Corrigan, P., and Joyce, P. (1997). Reconstructing public management: A new responsibility for the public and a case study of local government, International Journal of Public Sector Management, 10:6; 417-432.

Cosgrave, E., Arbuthnot, K., \& Tryfonas, T. (2013). Living labs, innovation districts and information marketplaces: A systems approach for smart cities, Procedia Computer Science, 16, 668-677.

Dameri, R. P. (2017). The Conceptual Idea of Smart City: University, Industry, and Government Vision. In Smart City Implementation (pp. 23-43). Springer International Publishing.

Etzkowitz, H., \& Leydesdorff, L. (1995). The Triple Helix--University-industry-government relations: A laboratory for knowledge based economic development.

European Commission. (2010). EUROPE 2020: A European strategy for smart, sustainable and inclusive growth. Communication from The Commission, available at: http://ec.europa.eu/eu2020/pdf/COMPLET\%20EN\%20BARROSO\%20\%20\%20007\%20\%20Europe\%202020\%20-\%20EN\%20version.pdf.

European Commission. (2015). Perspectives for Research and Innovation Strategies for Smart Specialisation (RIS3) in the wider context of the Europe 2020 Growth Strategy. Luxembourg: Publications Office of the European Union, 2015. ISBN 978-92-79-49245-7 doi: $10.2777 / 872170$.

European Parliament. (2014). Mapping smart city in the EU. Brussels. Retrieved from http://www.europarl. europa.eu/thinktank/en/document.html?reference $1 / 4$ IPOLITRE_ET\%282014\%29507480

European Union. (2011). Cities of tomorrow: Challenges, visions, ways forward. Communication, Information, Relations with Third Countries, Brussels. doi:10.2776/41803.

Francesco B., Marco T. and Cristina C. (2017). Co-Governing Smart Cities Through Living Labs. Top Evidences From Eu, Transylvanian Review of Administrative Sciences, No. 50 E/2017, pp. 21-37. DOI:10.24193/tras.2017.0002.

FindAMasters.com. (2017). Find A Masters Degree Worldwide - Postgraduate MSc MA MBA MPhil MRes MBA \& LLM Courses. [online] Available at: https://www.findamasters.com/ [Accessed 23 Oct. 2017].

Giffinger, R., Fertner, C., Kramar, H., Kalasek, R., Pichler-Milanovic, N. and Meijers, E. (2007). Smart Cities-Ranking of European Medium-sized Cities. [Online] available at http://www.smart-cities.eu/download/smart_cities_fi nal_report, accessed on March 15, 2016.

Griffith, J. C. (2000). Smart governance for smart growth: The need for regional governments. Ga. St. UL Rev., 17, 1019.

GSMA. (2012) 'Finland: Forum Virium Helsinki', GSMA Connected Living, Available at: http://www.gsma.com/connectedliving/wpcontent/uploads/2012/12/cl_forum_virium_12_12. pdf.

Hannele A., Aapo H., Isabel P. and Miimu A. (2016). What are the differences between sustainable and smart cities?, Elsevier Ltd, Cities 60 pp 234-245.

Helsinki Region Infoshare (HRI). (2013) 'About Helsinki Region Infoshare'. Available at: http://www.hri.fi/en/about/. 
Chourabi, H., Nam, T., Walker, S., Gil-Garcia, J.R., Mellouli, S., Nahon, K., Pardo, T.A. and Scholl, H.J. (2012). Understanding smart cities: An integrative framework. In System Science (HICSS), 2012 45th Hawaii International Conference on(pp. 2289-2297). IEEE.

Kourtit, K., Macharis, C., \& Nijkamp, P. (2014). A multi-actor multi-criteria analysis of the performance of global cities, Applied Geography, 49, 24-36.

Le Boterf, G. (1994). De la compétence. Essai sur un attracteur étrange.Lee, J. H., \& Hancock, M. G. (2012). Towards a framework for smart cities: A comparison of Seoul, San Francisco and Amsterdam. Stanford Program on Regions of Innovation and Entrepreneurshiphttp://iisdb.stanford.edu/evnts/7239/Jung_Hoon_Lee_final.pdf

Leydesdorff, L., \& Etzkowitz, H. (2001). The transformation of university-industry-government relations. Electronic journal of Sociology.

Major Cities of Europe, 'Barcelona Urban Habitat, The vision, approach and projects of the City of Barcelona towards smart cities', Vienna, 6th June 2012.

Maroula A., Diofantos H., Phaedon K. and Konstantinos S. (2016). "Smart City planning from a bottom-up approach: local communities' intervention for a smarter urban environment", Proc. SPIE 9688, Fourth International Conference on Remote Sensing and Geoinformation of the Environment. doi: 10.1117/12.2240762.

Michelucci, F. V., De Marco, A., \& Tanda, A. (2016). Defining the Role of the Smart-City Manager: An Analysis of Responsibilities and Skills, Journal of Urban Technology, 23(3), 23-42.

Mulder, I. (2014). Sociable smart cities: Rethinking our future through co-creative partnerships. In N. Streitz \& P. Markopoulos (Eds.), Distributed, ambient, and pervasive interactions (pp. 566-574). Heidelberg, Germany: Springer.

Nalbandian, J., R., O'Neill, J. Michael Wilkes, and J. Kaufman, (2013). Contemporary Challenges in Local Government: Evolving Roles and Responsibilities, Structures, and Processes, Public Administration Review, 73:4; 567-574.

Nam, T., \& Pardo, T. A. (2011). Conceptualizing Smart City with dimensions of technology, people, and institutions. In Proceedings of the 12th annual international digital government research conference: digital government innovation in challenging times (pp. 282-291). ACM.

Odendaal, N. (2003). Information and communication technology and local governance: Understanding the difference between cities in developed and emerging economies, Computers, Environment and Urban Systems, 6(27), 585-607.

Official webpage European Commission (2017 a). The Directorate-General for Communications Networks, Content and Technology. https://ec.europa.eu/info/departments/communicationsnetworks-content-and-technology_en.

Official webpage European Commission (2017 b). European commission Mobility and transport Available at: https://ec.europa.eu/transport/index_en.

Official webpage European Commission (2017). European commission on Smart Cities. Available at: https://ec.europa.eu/digital-single-market/en/policies/smart-cities .

Official webpage of 'The Copenhagen Wheel' (TCW). (2017). About the project Copenhagen Wheel. Available at: http://senseable.mit.edu/copenhagenwheel/index.html.

Official webpage of Smart City Wien (SCW). (2017). Project 'Smile - einfach mobil', available at: https://smartcity.wien.gv.at/site/en/smile-2/.

Porter, M. (1990). The competitive advantage of nations. New York: The Free Press.

Rychen, D. S., \& Salganik, L. H. (Eds.). (2003). Key competencies for a successful life and wellfunctioning society. Hogrefe Publishing.

Santoro, R., \& Conte, M. (2009). Living labs in open innovation functional regions. In Technology Management Conference (ICE), 2009 IEEE International (pp. 1-8). IEEE.

Shapiro, J. M. (2006). Smart cities: Quality of life, productivity, and the growth effects of human capital, Review of Economics \& Statistics, 88, 324-335. 
Schaffers, H., \& Turkama, P. (2012). Living Labs for cross-border systemic innovation, Technology Innovation Management Review, 2(9), 25.

Scholl, H. J., \& Scholl, M. C. (2014). Smart governance: A roadmap for research and practice. In M. Kindling \& E. Greifeneder (Eds.), iConference 2014 Proceedings (pp. 163-176). UrbanaChampaign, USA: iSchools.

Tan Y. (2016). Technology and the City: Systems, Applications and Implications. Published by Routledge. 2 Park Square, Milton Park, Abington. ISBN 9781315739090.

The Official Webpage of Amsterdam Smart City (ASC). (2017). Amsterdam Smart City initiatives. Available at: https://amsterdamsmartcity.com.

Torfing JB, Peters G, Pierre J and Sorensen, E. (2012). Interactive Governance: Advancing the Paradigm. Oxford: Oxford University Press.

Waart, van, P., Mulder, I., \& de Bont, C. (2016). A participatory approach for envisioning a Smart City, Social Science Computer Review, 34(6), 708-723.

Virtanen, T. (2000). Changing competences of public managers: tensions in commitment, International Journal of Public Sector Management, 13:4; 333-341.

Wang, M. (2015). Smart cities of the future: Creating tomorrow's education toward effective skills and career development today, Knowledge Management \& E-Learning: An International Journal (KM\&EL), 6(4), 344-355.

YouTube. (2017). The Future is Smarter Cities by Jerry MacArthur Hultin. [online] Available at: https://www.youtube.com/watch?v=sgeZiCzQamA [Accessed 23 Oct. 2017].

Zagorsek, H., Svetina, A. C., \& Jaklic, M. (2008). Leadership in clusters: Attributes of effective cluster leader in Slovenia, Transformations in Business and Economics, 7(2), p. 98-113. 